\title{
Workshop pembuatan video pembelajaran kreatif bagi guru matematika SMP Se-Kota Mataram
}

\section{Syahrul Azmi ${ }^{1 *}$, Ketut Sarjana ${ }^{2}$, Junaidi ${ }^{3}$, Ratna Yulis Tyaningsih $^{4}$, Wahidaturrahmi ${ }^{5}$}

1,2,3,4,5 Pendidikan Matematika, FKIP, Universitas Mataram, Mataram

syahrulazmi.fkip@unram.ac.id

\begin{abstract}
:
This community service activity aims to improve teachers' abilities to create video lessons that could be used either on online learning or in person. The activity's strategy was a workshop that mainly focused on working and creating video lessons after giving a brief explanation on how to produce the video. The workshop also involves pre and post-test to assess the improvement of participants' competence. This activity resulted in video lessons uploaded on the Youtube channel, and participants' assessment scores improved from 65,8 to 76,9 . Therefore, teachers involved in this social service admitted that they benefit from joining the workshop as they are now able to create exciting video lessons that might raise students' enthusiasm and motivation in the learning process.
\end{abstract}

Keywords: workshop, video lesson, creative learning

\begin{abstract}
Abstrak:
Kegiatan pengabdian kepada masyarakat ini berupa workshop yang hasil akhirnya berupa produk video pembelajaran matematika yang dapat dimanfaatkan guru sebagai salah satu media pembelajaran baik dalam pembelajaran daring maupun luring. Tujuan dari kegiatan ini adalah a) Memberikan gambaran tentang video pembelajaran dan aplikasi yang dapat digunakan untuk membuat video pembelajaran yang menarik, dan b) Memberikan pelatihan tentang cara pembuatan video pembelajaran. Metode yang digunakan adalah ceramah untuk menjelaskan materi, dilanjutkan dengan tanya jawab dan praktek. Tim juga memberikan tes (pretest dan postest). Dari hasil kegiatan, dihasilkan produk berupa video pembelajaran yang di upload di youtube, dan dapat digunakan sebagai salah satu media pembelajaran matematika. Selain itu didapatkan data tentang nilai rata-rata hasil pretest dan posttest berturut-turut yaitu 65,8 dan 76,9. Terjadi peningkatan nilai rata-rata hasil test sebesar 11,2 poin. Berdasarkan hasil kegiatan, dapat disimpulkan bahwa kegiatan pengabdian kepada masyarakat ini dirasakan sangat bermanfaat dalam meningkatkan pengetahuan dan keterampilan para guru tentang cara pembuatan video pembelajaran yang menarik sehingga dapat meningkatkan antusiasme dan minat siswa dalam belajar matematika.
\end{abstract}

Kata Kunci: workshop, video pembelajaran, pembelajaran kreatif

\section{PENDAHULUAN}

Situasi yang terjadi sekarang ini masih dalam masa pandemic Corona Virus Disease (COVID-19). Pandemi COVID-19 adalah krisis kesehatan yang sedang terjadi di dunia. Penyebaran virus corona ini sangat berdampak pada dunia pendidikan membuat pemerintah pusat hingga pemerintah daerah mengambil kebijakan untuk meniadakan kegiatan belajar tatap muka di sekolah, atau pembelajaran tatap muka terbatas di sekolah. Hal ini dilakukan sebagai upaya mencegah meluasnya COVID-19. Kebijakan ini diharapkan dapat meminimalisir menyebarnya COVID-19. Akibat Kebijakan ini, baik 
pemerintah maupun lembaga terkait harus menghadirkan alternatif proses pendidikan bagi peserta didik yang tidak bisa melaksanakan proses pendidikan pada lembaga pendidikan. Sebagai alternatif pelaksanaan pendidikan di Indonesia, saat ini beberapa sekolah sudah menerapkan kegiatan belajar mengajar jarak jauh atau online yang lebih dikenal dengan istilah Belajar dari Rumah (BDR).

Dengan adanya kebijakan belajar dari rumah, guru mempunyai beberapa cara dalam menyampaikan materi dan memberi tugas serta melakukan evaluasi yaitu dengan melalui aplikasi belajar online dan media pembelajaran. Media pembelajaran yang bisa digunakan peserta didik untuk belajar di rumah salah satunya yaitu video pembelajaran. Berbagai hasil penelitian menunjukkan bahwa orang lebih tertarik belajar menggunakan media video daripada belajar melalui media teks dan gambar diam (Fadhli, 2015).

Video merupakan salah satu media pembelajaran yang dapat digunakan untuk menunjang pembelajaran. Pemanfaatan media pembelajaran menjadi salah satu faktor yang mendukung tercapainya tujuan pembelajaran. Menurut Kamus Besar Bahasa Indonesia, video merupakan rekaman gambar hidup atau program televisi untuk ditayangkan lewat pesawat televisi (KBBI, 2021), atau dengan kata lain video merupakan tayangan gambar bergerak yang disertai dengan suara. Susilana dan Riyana (2009) menyebutkan bahwa video disebut juga gambar hidup (motion picture) yaitu, serangkaian gambar yang meluncur secara cepat, dan diproyeksikan sehingga menimbulkan kesan seperti nyata. Menurut Suharidjadi (dalam Firmansyah, 2020), beberapa prinsip dasar yang harus diperhatikan dalam pembuatan video pembelajaran diantaranya adalah: 1) konsep awal video pembelajaran, yang berisi narasi apa yang akan dibawakan, scene untuk setiap bagian narasi, 2) sinematik, meliputi property apa yang digunakan, penampilan, ukuran dan jenis font, 3) teknik merekam, meliputi aplikasi dan alat untuk merekam, serta media penyimpanan, dan 4) durasi waktu ideal sebuah video pembelajaran, yaitu maksimal sekitar 15 menit video pembelajaran yang padat dan berisi materi lengkap yang sudah direncanakan dalam narasi sebelum pembuatan

Dengan membuat video pembelajaran yang menarik tentunya akan membuat proses pembelajaran jarak jauh menjadi lebih efektif. Mengapa demikian?, Pembelajaran yang dilakukan dengan media video efektif membuat anak bisa menerima pembelajaran yang diberikan kepadanya (Putri, 2012). Siswa lebih tertarik melihat grafik dan gambargambar daripada membaca tulisan yang banyak. Video pembelajaran dapat digunakan oleh siswa secara individual dan dapat diputar oleh siswa dimana saja dan kapan saja. Siswa dapat mengulang memutar video materi pembelajaran sampai mereka benarbenar memahami materi tersebut. Pembuatan video pembelajaran dapat dilakukan dengan memanfaatkan beberapa aplikasi, diantaranya kinemaster, Camtasia, powtoon, atau langsung membuat video dengan melakukan perekaman di powerpoint dengan menampilkan wajah.

Berdasarkan fakta dilapangan, tidak semua guru, terutama guru SMP yang mengajar mata pelajaran matematika di kota Mataram, sudah memahami dengan baik bagaimana cara membuat video pembelajaran ataupun alat evaluasi yang menarik, yang dapat diberikan secara daring. Banyak juga para guru yang belum mengetahui cara membuat 
video pembelajaran sebagai salah satu sumber belajar bagi siswa dalam masa pendemi ini. Kenyataannya, para guru banyak yang hanya mengirimkan materi dalam bentuk teks atau langsung tugas melalui aplikasi Whatsapp saja. Akibatnya banyak siswa yang masih belum memahami materi yang dipelajari, karena siswa hanya berusaha memahami materi dari tulisan yang dikirimkan oleh guru.

Berdasarkan permasalahan tersebut, maka dipandang perlu untuk diadakan kegiatan pengabdian bagi guru matematika SMP di kota Mataram dengan judul : Workshop Pembuatan Video Pembelajaran Kreatif Bagi Guru Matematika SMP Se-Kota Mataram. Kegiatan yang dilakukan berupa pelatihan pembuatan video pembelajaran yang menarik, yang memuat teks, gambar, suara,ataupun animasi lainnya bagi guru SMP yang mengajar matematika di kota Mataram, sampai pada kegiatan menghasilkan produk berupa video pembelajaran yang dapat digunakan sebagai salah satu sumber belajar. Khalayak sasarannya adalah para guru matematika SMP se-Kota Mataram yang tergabung dalam MGMP Matematika Kota Mataram. Sehingga tujuan kegiatan ini adalah a) Memberikan gambaran tentang bermacam-macam aplikasi yang dapat digunakan untuk membuat video pembelajaran yang menarik yang dapat digunakan dalam pembelajaran daring maupun luring, serta b) Memberikan pelatihan tentang cara pembuatan video pembelajaran

\section{METODE PELAKSANAAN}

Kegiatan Pengabdian dilaksanakan di SMPN 15 Mataram, dengan peserta yang terlibat adalah guru-guru matematika yang tergabung dalam forum MGMP Matematika Kota Mataram. Para guru ini merupakan guru-guru Matematika yang mengajar di SMP/MTs yang berada di wilayah Kota Mataram.

Metode yang digunakan dalam kegiatan pengabdian ini berupa pelatihan pembuatan video pembelajaran kreatif bagi guru matematika SMP di kota Mataram. Adapun langkah-langkah pelaksanaan kegiatan pengabdian adalah sebagai berikut:

a) Memberikan soal pretest untuk mengetahui pengetahuan awal para guru tentang video pembelajaran, prinsip pembuatan, persiapan, serta langkah-langkah pembuatan video pembelajaran

b) Melakukan kegiatan ceramah dan tanya jawab yang langkah-langkah kegiatannya adalah:

1) Pada kegiatan ini tim pengabdian memberikan penjelasan singkat mengenai video pembelajaran, persiapan sebelum dan saat membuat video pembelajaran, langkah-langkah membuat video pembelajaran, hal yang harus diperhatikan saat membuat video, prinsip pembuatan video, serta unsur-unsur apa saja yang harus termuat dalam suatu video pembelajaran

2) Secara bergantian tim memberikan penjelasan sekaligus meminta peserta praktek langsung cara pembuatan video pembelajaran dengan menggunakan aplikasi offline maupun online, yaitu menggunakan kinemaster, camtasia, powtoon, dan ppt slide show recorder. 
3) Memberikan soal postets untuk mengetahui sejauh mana para guru menyerap materi yang telah disampaikan.

\section{HASIL DAN PEMBAHASAN}

\subsection{HASIL KEGIATAN}

Untuk memecahkan permasalahan yang telah dirumuskan pada kegiatan ini, telah dilakukan kegiatan pengabdian pada tanggal 28 Agustus 2021 di SMPN 15 Mataram. Pesertanya adalah para guru matematika SMP yang tergabung dalam MGMP Matematika di Kota Mataram. Kegiatan pertama yang dilakukan adalah memberikan tes awal untuk mengetahui pengetahuan awal para guru tentang pemahaman mereka tentang video pembelajaran, persiapan sebelum membuat video pembelajaran, langkahlangkah membuat video pembelajaran, hal yang harus diperhatikan saat membuat video, prinsip pembuatan video, serta unsur-unsur apa saja yang harus termuat dalam suatu video pembelajaran. Dalam tes awal juga termuat pertanyaan durasi ideal untuk sebuah tayangan video pembelajaran yang baik, dan tidak membosankan untuk ditonton siswa. Kegiatan berikutnya adalah memberikan penjelasan umum mengenai video pembelajaran, persiapan sebelum membuat video pembelajaran, langkah-langkah membuat video pembelajaran, hal yang harus diperhatikan saat membuat video, prinsip pembuatan video, serta unsur-unsur apa saja yang harus termuat dalam suatu video pembelajaran. Selanjutnya secara bergantian, tim pengabdian menjelaskan beberapa aplikasi yang dapat digunakan untuk membuat video pembelajaran. Dimulai dengan penggunaan aplikasi Kinemaster, fitur-fitur yang terdapat didalam aplikasi tersebut, serta contoh cara pembuatan video dengan aplikasi tersebut. Anggota tim berikutnya memberikan penjelasan penggunaan aplikasi Camtasia dan contoh pembuatan video pembelajaran dengan menggunakan aplikasi tersebut. Software berikutnya yang dijelaskan adalah penggunaan software Powtoon untuk membuat video pembelajaran. Anggota tim menjelaskan tentang fitur-fitur yang terdapat dalam software tersebut serta memberikan contoh cara membuat video dengan software tersebut. Dibagian paling akhir diberikan contoh cara membuat video pembelajaran dengan merekam langsung dari tayangan powerpoint dengan menggunakan powerpoint record slide show.

Dari hasil praktek pembuatan video pembelajaran dihasilkan sebuah video pembelajaran yang dibuat dengan software powtoon, yang kemudian di upload di youtube.

Kegiatan pengabdian ditutup dengan memberikan tes akhir (posttest) kepada para guru yang mengikuti kegiatan pengabdian untuk mengetahui sejauhmana pemahaman para guru dalam menerima materi pengabdian yang diberikan. Data hasil pretest dan posttes kegiatan pengabdian ditunjukkan pada Tabel 1.

Tabel 1. Hasil pretest dan posttest peserta pengabdian bagi guru Matematika SMP di Kota Mataram

\begin{tabular}{lll}
\hline Nilai & Pretest & Posttest \\
\hline
\end{tabular}




\begin{tabular}{lcc}
\hline Nilai terendah & 43,8 & 59,4 \\
Nilai tertinggi & 71,9 & 90,6 \\
Rata-rata & 65,8 & 76,9 \\
\hline Peningkatan nilai rata-rata & \multicolumn{2}{c}{11,2} \\
\hline
\end{tabular}

Berdasarkan pertanyaan yang diajukan di bagian awal kegiatan, diketahui beberapa hal sebagai berikut:

Tabel 2. Hasil data penggunaan video pembelajaran peserta pengabdian guru MGMP Matematika di Kota Mataram

\begin{tabular}{llc}
\hline No. & Pernyataan & $\begin{array}{c}\text { Banyak } \\
\text { Peserta }\end{array}$ \\
\hline 1. & $\begin{array}{l}\text { Membuat video pembelajaran matematika dengan } \\
\text { aplikasi (misal: PPT, Kinemaster, AZ Screen recorder, }\end{array}$ & \\
& dll) & 13 \\
2 & $\begin{array}{l}\text { Membuat video pembelajaran matematika langsung } \\
\text { dari kamera HP }\end{array}$ & 2 \\
$3 \quad$ Tidak membuat video pembelajaran & 5 \\
\hline & Jumlah & 20 \\
\hline
\end{tabular}

\subsection{Pembahasan}

Kegiatan pengabdian ini bertujuan untuk a) Memberikan gambaran tentang bermacammacam aplikasi yang dapat digunakan untuk membuat video pembelajaran yang dapat digunakan sebagai salah satu sumber belajar yang menarik bagi siswa, b) Memberikan pelatihan tentang cara pembuatan video pembelajaran yang menarik, yang memuat teks, gambar, suara, dan efek animasi lainnya.

Dari hasil kegiatan diketahui bahwa terjadi peningkatan nilai rata-rata hasil tes para guru, dimana rata-rata pretest sebesar 65,8 , meningkat menjadi 76,9 . Terlihat bahwa terjadi peningkatan nilai rata-rata sebesar 11,2 poin. Terjadinya peningkatan hasil ini disebabkan karena para guru dapat menyerap dengan baik materi yang disajikan oleh tim. Pada kegiatan penjelasan materi tentang video pembelajaran, bagaimana membuat dan menggunakan dalam kegiatan pembelajaran, unsur-unsur yang harus termuat dalam suatu video pembelajaran yang baik, serta hal-hal yang harus disiapkan sebelum membuat video pembelajaran. Menurut Suharidjadi (dalam Firmansyah, 2020), beberapa prinsip dasar yang harus diperhatikan dalam pembuatan video pembelajaran diantaranya adalah: 1) konsep awal video pembelajaran, yang berisi narasi apa yang akan dibawakan, scene untuk setiap bagian narasi, 2) sinematik, meliputi property apa yang digunakan, penampilan, ukuran dan jenis font, 3) teknik merekam, meliputi aplikasi dan alat untuk merekam, serta media penyimpanan, dan 4) durasi waktu ideal sebuah video pembelajaran, yaitu maksimal sekitar 15 menit video pembelajaran yang padat dan berisi materi lengkap yang sudah direncanakan dalam narasi sebelum pembuatan.

Kegiatan selanjutnya adalah penjelasan tentang aplikasi kinemaster. Kinemaster merupakan sebuah aplikasi smartphone yang khusus digunakan untuk keperluan 
editing video. Aplikasi ini cukup simple dan dapat digunakan untuk mengedit sebuah video hanya melalui perangkat HP saja. Fitur-fitur pada kinemaster ini sudah lengkap seperti halnya aplikasi editing video lainnya. Beberapa fitur pada kinemaster diantaranya Project Assistant, Dukungan Media, Audio, Text, Tema, dan Tool Editing (Anonim, 2020). Semua fitur ini sangat mudah digunakan oleh guru dalam membuat sebuah video yang menarik. Hal ini disebabkan karena kinemaster mendukung banyak lapisan video, audio, gambar, teks, dan efek dilengkapi dengan macam-macam alat yang memungkinkan guru membuat video berkualitas tinggi. Materi pelajaran didesain semenarik mungkin, dapat menampilkan video, serta gambar-gambar animasi yang berhubungan dengan materi pelajaran agar peserta didik lebih fokus terhadap apa yang disampaikan oleh pengajar. Selain itu, video KineMaster dapat langsung dibagikan ke platform media sosial seperti YouTube, WhatsApp, Facebook, Google+, dan banyak lagi. Ini memudahkan, terutama bagi para guru, untuk mempublikasikan video mereka dan menjangkau peserta didik. Proses pembelajaran akan lebih menggembirakan sehingga berpengaruh pada peningkatan minat belajar peserta didik (Khaira, 2021).

Aplikasi kedua yang dijelaskan oleh tim adalah Camtasia studio. Camtasia adalah software (perangkat lunak) yang dikembangkan oleh TechSmith Coorporation, dan digunakan untuk merekam semua aktifitas yang ada pada desktop komputer. Software ini bisa dimanfatkan untuk membuat media pembelajaran berbasis multimedia dan elearning (Hardiyana, 2021). Navigasi utama yang terdapat dalam Camtasia ini diantaranya adalah record, edit, produce, dan share. Saat proses perekaman dengan menggunakan camtasia ini, beberapa hal yang harus dipersiapkan diantaranya adalah 1) rancangan alur video, dalam hal ini diperlukan agar dalam membuat video menjadi lebih terarah dan terorganisir, 2) naskah video tutorial untuk memperkecil kesalahan dalam membuat video, 3) media penunjang, seperti microphone, bahan presentasi, atau web cam apabila diperlukan, dan 4) pastikan desktop bersih dari aplikasi yang tidak diperlukan agar proses perekaman menjadi tidak terhambat.

Perangkat lunak berikutnya yang dijelaskan tim adalah powtoon. Powtoon adalah aplikasi web berbasis IT yang dapat digunakan sebagai media pembelajaran yang di dalamnya terdapat fitur-fitur menarik seperti fitur untuk membuat presentasi atau video animasi yang dapat digunakan dengan mudah dan menarik (Ernalida, Lidyawati, Ansori, Gafur, Hikmah, 2018). Media pembelajaran Powtoon ini memiliki kelebihan yaitu banyaknya fitur animasi yang bermacam-macam serta efek yang membuat presentasi atau video pembelajaran terlihat menarik. Selain itu, time line yang terdapat dalam Powtoon juga dapat digunakan dengan mudah dibandingkan aplikasi-aplikasi lain yang sejenis dengannya (Anggita, 2021). Media pembelajaran animasi PowToon lebih banyak menyediakan animasi daripada aplikasi lainnya. Animasi tersebut juga dapat diatur dengan mudah sesuai dengan keinginan penggunanya sehingga mudah digunakan untuk memberikan suatu ilustrasi yang berkaitan dengan materi yang akan disajikan. Animasi PowToon adalah suatu aplikasi yang memiliki fitur canggih dalam satu layar, yang dapat membuat berbagai animasi sesuai kebutuhan yang diperlukan (Awalia et al., 2019). 
Aplikasi ini mudah digunakan dalam membuat video pembelajaran yang menarik, sehingga nantinya diharapkan dapat meningkatkan minat siswa dalam belajar matematika. Hasil penelitian Awalina, dkk (2019) yang menggunakan media pembelajaran powtoon pada materi keliling dan luas bangun datar memberikan hasil skor rata-rata 76, 14 dan berada pada kategori baik.

Aplikasi terakhir yang dijelaskan oleh tim adalah penggunaan powerpoint record slide show. Penggunaan aplikasi ini sangat mudah dan paling sederhana digunakan karena tidak memerlukan aplikasi lain dalam penggunaannya. Aplikasi ini tidak memerlukan jaringan internet, hanya menggunakan materi-materi yang sudah ada dalam laptop atau computer. Pembuatan video dapat dilakukan dengan mengklik menu "Slide Show" lalu pilih "record from current slide" pada bagian atas Powerpoint. Setelah tampilan untuk recording muncul, pastikan tombol mic pada bagian bawah sudah aktif. Klik "record" untuk memulai rekaman. Selanjutnya adalah menjelaskan narasi terkait slide yang telah dibuat hingga slide terakhir. Proses rekaman dapat dijeda dengan mengklik tombol "pause". Selanjutnya apabila rekaman sudah selesai, maka dapat mengklik tombol "stop". File dapat disimpan dalam bentuk video dengan cara mengklik: File - Export - Create a video, lalu pilih jenis file HD (720p) dan "use recorded timings and narrations". Isi 1 detik pada "seconds spent on each slide". Tahap terakhir adalah mengklik "create a video" untuk mengonversi file menjadi video. Tunggu hingga proses rendering selesai dan video siap digunakan (Agusta, dkk, 2020).

Pada saat kegiatan presentasi materi dan demontrasi tentang cara pembuatan dan editing video pembelajaran, peserta diminta praktek langsung membuat video pembelajaran dengan menggunakan aplikasi kinemaster, camtasia studio, powtoon, maupun menggunakan ppt record slide show. Sebelum praktek dimulai, tim terlebih dahulu memastikan bahwa aplikasi tersebut sudah terinstal dalam HP ataupun laptop masing-masing. Selanjutnya tim meminta guru untuk menyiapkan beberapa foto, gambar, ataupun video pendek yang akan digabung dalam aplikasi tersebut sehingga menjadi satu video utuh. Peserta terlihat antusias mengikuti penjelasan dan langsung mempraktekkan sesuai arahan yang diberikan oleh tim. Saat kegiatan peserta juga aktif bertanyajawab dengan tim apabila ada hal yang belum dipahami dalam pembuatan video yang menarik.

Dari hasil tanya jawab dengan 20 peserta pengabdian, diketahui beberapa hal sebagai berikut:

1. Sebanyak 5 peserta menyatakan tidak pernah membuat video pembelajaran untuk mendukung kegiatan pembelajaran secara daring. Mereka hanya mengirimkan materi pelajaran dalam bentuk teks saja.

2. Sebanyak 2 orang peserta menyatakan membuat video pembelajaran dengan merekam langsung saat mengajar, sehingga kualitas video yang dihasilkan menjadi kurang menarik, durasi video juga lebih dari 30 menit 
3. Sebanyak 13 peserta menyatakan pernah membuat video pembelajaran, dengan menggunakan aplikasi yang beragam. Walaupun demikian, mereka menyatakan kurang memahami dengan baik cara pembuatan dan editing video sehingga menjadi video pembelajaran yang menarik. Para guru menyadari bahwa video pembelajaran yang dihasilkan belum memuat semua unsur-unsur dasar video yang baik, tidak mempersiapkan storyboard terlebih dahulu, dan komposisi suara dan gambar yang dihasilkan masih belum seimbang.

Oleh karenanya dengan adanya kegiatan pengabdian ini para guru mendapatkan pengetahuan dan pengalaman tentang bagaimana membuat dan mengedit sebuah video sehingga menjadi sebuah video pembelajaran yang menarik, konsep materi tersajikan secara menarik dan utuh, serta tidak membuat siswa bosan untuk belajar matematika. Diharapkan nantinya penggunaan video dalam kegiatan pembelajaran dapat meningkatkan hasil belajar peserta didik. Penelitian tentang penggunaan video pembelajaran oleh Ridha, dkk (2021) menunjukkan bahwa Media video pembelajaran efektif dilaksanakan pada masa pandemi Covid-19, karena memudahkan pendidik dalam mengajarkan materi serta memudahkan peserta didik memahami materi pembelajaran. Begitu juga penelitian yang dilakukan oleh Hanani (2021) menunjukkan bahwa pembelajaran dengan memanfaatkan media yang berbasis video dapat meningkatkan minat dan motivasi peserta didik dari 21,4\% meningkat menjadi 79,5\%. Penelitian tentang video pembelajaran juga dilakukan oleh Syah \& Risnawati (2019) menunjukkan bahwa berdasarkan hasil uji hipotesis, dapat disimpulkan bahwa media video efektif terhadap aktivitas dan hasil belajar siswa. Setelah kegiatan pengabdian diharapkan para guru dapat lebih sering membuat video pembelajaran yang menarik yang dapat mendukung guru dalam pelaksanaan pembelajaran, khususnya saat pembelajaran dilakukan secara daring, sehingga pada akhirnya akan dapat meningkatkan hasil belajar peserta didik.

\section{SIMPULAN}

Kegiatan pengabdian pada masyarakat ini dirasakan sangat bermanfaat bagi guru-guru SMP yang tergabung dalam MGMP Matematika di Kota Mataram. Kebermanfaatan kegiatan ini ditunjukkan dengan adanya peningkatan pengetahuan para guru tentang video pembelajaran, bagaimana membuat dan mengedit sebuah video sehingga tampilannya menjadi menarik, hal-hal apa saja yang perlu dipersiapkan sebelum dan pada saat membuat video, serta aplikasi apa yang dapat digunakan untuk membuat sebuah video pembelajaran, baik aplikasi offline maupun online. Peningkatan pemahaman ini juga terlihat dari nilai rata-rata hasil tes yang diberikan, terjadi peningkatan dari 65,8 menjadi 76,9 (meningkat sebesar 17,02\%). Dari hasil ini terlihat bahwa tujuan kegiatan pengabdian pada masyarakat telah tercapai. Dan dari hasil kegiatan pengabdian ini diharapkan para guru-guru dapat meningkatkan kualitas pembelajaran matematika di kelas baik saat dilaksanakan secara daring, maupun pembelajaran secara luring. 


\section{UCAPAN TERIMA KASIH}

Ucapan terima kasih disampaikan sebesar-besarnya kepada:

1. Dekan FKIP Unram

2. Ketua MGMP Matematika Kota Mataram atas kerjasama yang baik

3. Kepala Sekolah SMPN 15 Mataram atas waktu dan tempat yang disediakan

4. Para guru terutama guru yang tergabung dalam Forum MGMP Matematika Kota Mataram

5. Para rekan Tim Pengabdian dari program studi Pendidikan Matematika

\section{REKOMENDASI}

Setelah diadakan kegiatan pengabdian pada masyarakat ini, tim menyarankan pada peserta agar dalam pembelajaran matematika agar lebih meningkatkan kemampuan diri dan proses pembelajaran, salah satunya dengan mengoptimalkan semua sumber dan media belajar yang ada, terlebih dalam situasi sekarang ini yang masih belum terbebas dari pandemi covid-19. Salah satu cara untuk membuat pembelajaran matematika tetap menyenangkan adalah dengan menggunakan video pembelajaran, yang berisi materi pelajaran, yang disajikan secara jelas, dilengkapi dengan suara dan gambar-gambar yang sesuai, serta efek dan animasi yang menarik. Diharapkan juga bagi para guru-guru untuk saling bertukar informasi dengan guru-guru yang lain baik tentang teori maupun pelaksanaan pembelajaran dengan memanfaatkan video pembelajaran, supaya kualitas pembelajaran matematika di sekolah menjadi lebih baik lagi.

\section{REFERENSI}

Agusta, M. K., dkk. (2020). Panduan Pembuatan Video Ajar. Tim Pengembangan Inovasi Pembelajaran : Fakultas Teknologi Industri, ITB.

Anggita, Z. (2021). Penggunaan Powtoon Sebagai Solusi Media Pembelajaran Di Masa Pandemi Covid-19. Konfiks Jurnal Bahasa Dan Sastra Indonesia, 7(2), 44-52. https://doi.org/10.26618/konfiks.v7i2.4538

Anonim. (2020). Apa Itu Kinemaster ? Pengertian, Fungsi dan Fitur - Fiturnya. Tersedia online di: $\quad$ https://www.utopicomputers.com/apa-itu-kinemaster-pengertian-fungsi-dan-fiturfiturnyal

Awalia, I., Pamungkas, A. S., \& Alamsyah, T. P. (2019). Pengembangan Media Pembelajaran Animasi Powtoon pada Mata Pelajaran Matematika di Kelas IV SD. Kreano, Jurnal Matematika Kreatif-Inovatif, 10(1), 49-56. https://doi.org/10.15294/kreano.v10i1.18534

Ernalida, Lidyawati, Ansori, Gafur, Hikmah, U. (2018). Powtoon:Media Pembelajaran berbasis Teknologi Informasi sebagai Upaya dalam Menciptakan Pembelajaran yang Menarik dan Kreatif. Jurnal Logat, 5(02), 132-138.

Fadhli, M. (2015). Pengembangan Media Pembelajaran Berbasis Video Kelas Iv Sekolah Dasar. Jurnal Dimensi Pendidikan Dan Pembelajaran, 3(1), 24-29. https://doi.org/10.24269/dpp.v3i1.157

Firmansyah, M. (2020). Prinsip Video Pembelajaran Dalam Rangka Pembelajaran Online. Artikel Diterbitkan Di: https://radarsemarang.jawapos.com/rubrik/untukmuguruku/2020/10/10/membuat-video-pembelajaran-yang-menarik/ 
Hanani. (2021). Pemanfaatan Media Pembelajaran Berbasis Video Sebagai Alternatif Dalam Pembelajaran Daring IPA Di MTs. Negeri 1 Oku Timur. Edutech: Jurnal Inovasi Pendidikan Berbantuan Teknologi, 1(2), 88 - 95

Hardiyana, B. (2021). Teknik Multimedia: Merekam Video Dengan Camtasia Studio 8. Unikom.ac.id. Tersedia online di: https://repository.unikom.ac.id/55982/1/05.\%20MEREKAM\%20VIDEO\%20DENGAN\%20C AMTASIA\%20STUDIO\%208.pdf

KBBI, (2021). Arti kata video. Diambil dari : https://kbbi.kemdikbud.go.id/entri/video

Khaira, H. (2021). Pemanfaatan Aplikasi Kinemaster Sebagai Media Pembelajaran Berbasis ICT. Prosiding Seminar Nasional Pembelajaran Bahasa ..., $\quad$ 39-44. http://digilib.unimed.ac.id/id/eprint/41218

Putri, N. (2012). Efektifitas Penggunaan Media Video Untuk pada Pembelajaran IPS Bagi Anak Tunagrahita Ringan. Jurnal Ilmiah Pendidikan Khusus, 1(2), 318-328.

Ridha, Mhd., Firmansyah, Desyandri. (2021). Efektifitas Penggunaan Media Video pada Pembelajaran Tematik Terpadu di Sekolah Dasar Saat Pandemi Covid-19. Jurnal Pendidikan tambusai, 5(1), $154-162$

Susilana, Rudi dan Riyana, Chepi. (2009). Media Pembelajaran: Hakikat, Pengembangan, Pemanfaatan dan Penilaian. Bandung: CV. Wacana Prima. ISBN 9789791856119

Syah, I. M., Risnawati, S. (2019). Keefektifan Media Video Terhadap Aktivitas Dan Hasil Belajar Menulis Narasi Di SD. Elementary: Islamic Teacher Journal, 7(1), 139 - 148 